\title{
Pituitary-like Proopiomelanocortin Transcripts in Human Leydig Cell Tumors
}

Yves de Keyzer, Frédéric Lenne, Jean-Francis Massias, Didier Vieau, Jean-Pierre Luton, Axel Kahn, and Xavier Bertagna Centre de Recherche sur les Maladies Endocriniennes and Institut National de la Santé et de la Recherche Medicale (INSERM) U-129, Hôpital Cochin, 75674 Paris Cedex 14, France

\begin{abstract}
Proopiomelanocortin is a polypeptide precursor molecule, the processing of which generates ACTH, $\beta$-endorphin, the $\beta$ - and $\gamma$-lipotropins, the joining peptide, and the $\mathrm{NH}_{2}$-terminal fragment. Anterior pituitary corticotrophs are the major site of proopiomelanocortin gene expression in man and the predominant, if not sole source of circulating ACTH. Recent data have established that proopiomelanocortin gene expression also occurs in various normal nonpituitary tissues, one of the best studied being the testis. In this latter organ the dominant gene products are short transcripts of $\sim \mathbf{8 0 0}$ nucleotides, which lack the first two exons of the gene and cannot encode a complete proopiomelanocortin molecule. In this report we show that the mode of proopiomelanocortin gene expression is occasionally modified in human Leydig cell tumors: a 1,200-nucleotide mRNA species identical to that in the pituitary is produced. It results from the usual (pituitary) start site of transcription and thus can encode the complete proopiomelanocortin molecule. In two out of six tumors, large amounts of the 1,200-nucleotide transcript led to a dramatic increase of $\sim$ 1,000-fold in proopiomelanocortin peptide concentrations as compared with the normal and peritumoral testis. Proopiomelanocortin processing in these tumors generates various peptide fragments including ACTH. These results may help to understand the mechanism of proopiomelanocortin expression in nonpituitary tumors and have implications for the more general phenomenon of ectopic hormone secretion. (J. Clin. Invest. 1990. 86:871-877.) Key words: proopiomelanocortin • mRNA • Leydig cell tumors
\end{abstract}

\section{Introduction}

ACTH derives from the posttranslational processing of proopiomelanocortin (POMC), ${ }^{1}$ a complex polypeptide precursor molecule (1-3). In most mammalian species a single functional gene per haploid genome encodes POMC (4-9). Two different cell types within the pituitary gland have long been recognized as the major sites of POMC gene expression; the

Address reprint requests to Dr. X. Bertagna, Cliniques des Maladies Endocriniennes et Métaboliques, Pavillon Cornil, Hôpital Cochin, 27, rue de Faubourg Saint Jacques, 75674 Paris Cedex 14, France. 90.

Received for publication 27 December 89 and in revised form 5 May

1. Abbreviations used in this paper: $\beta$ end, $\beta$ endorphin; CLIP, corticotropin-like intermediary lobe peptide; h, human; LPH, lipotropin; $\mathrm{MSH}$, melanocyte-stimulating hormone; $\mathrm{NT}, \mathrm{NH}_{2}$-terminal; nt, nucleotide; POMC, proopiomelanocortin.

J. Clin. Invest.

(C) The American Society for Clinical Investigation, Inc. 0021-9738/90/09/0871/07 \$2.00

Volume 86, September 1990, 871-877 anterior lobe corticotrophs and the intermediate lobe melanotrophs both contain high concentrations of a 1,100-1,200-nucleotide (nt) POMC mRNA (10-14). The coordinate proteolysis or processing of the generated POMC molecule produces various peptide fragments: an $\mathrm{NH}_{2}$-terminal fragment (NT), joining peptide, ACTH, $\beta$-lipotropin ( $\beta \mathrm{LPH})$, and a small but definite amount of $\gamma$-LPH and $\beta$-endorphin ( $\beta$ end) are formed in the anterior lobe of the pituitary (15-19); in the intermediate lobe, smaller peptides are released such as $\beta$-melanocytestimulating hormone $(\beta \mathrm{MSH})$, corticotropin-like intermediary lobe peptide (CLIP), and $\alpha \mathrm{MSH}(20,21)$. Thus the anterior pituitary corticotrophs appear as the predominant, if not the sole source of circulating ACTH.

Recently it has become clear that POMC peptides were normally present in extracts of many nonpituitary tissues such as the brain, the gastrointestinal tract, the adrenal medulla, the placenta, and the female and male gonads (22). One of the most extensively studied tissue is the testis. Immunocytochemical and in situ hybridization techniques have shown the presence of both POMC peptides and RNA within the Leydig cell $(23,24)$. These studies also revealed two unexpected findings: (a) the testis POMC RNA is shorter than the pituitary POMC mRNA, being $\sim 800 \mathrm{nt}$ long $(25,26)$. We and others have shown that it lacks exons 1 and 2 and results from heterogeneous start sites of transcription located between 41 and 162 nt downstream from the $5^{\prime}$ end of exon $3(27,28)$; $(b)$ theoretically this short, truncated RNA could code for most of the POMC molecule and generate peptides such as ACTH and $\beta$ end. Yet an intriguing phenomenon is that nonpituitary tissues in general, and particularly the testis, contain extremely low concentrations of POMC peptides in comparison to the (relatively) large concentrations of POMC RNAs (29, 30). These observations suggested that the short, 800-nt POMC RNAs were not translated into a POMC-like molecule or that their translation efficiency was somehow dramatically reduced.

Several reports have shown that nonpituitary tumors responsible for the ectopic ACTH syndrome always contained a predominant POMC mRNA identical to the 1,200-nt pituitary transcript, even though they originated from tissues which normally expressed the short, 800-nt POMC RNAs (31-34). On these grounds we suggested that a pituitary-like transcription initiation was a mandatory step for the production of a functional POMC mRNA in nonpituitary tissues, a phenomenon which might result from a transcriptional shift in cell initially producing the short RNA species or from elective cancerization of rare cells normally synthesizing the 1,200-nt transcript.

To investigate these processes further we chose to examine the mechanism of POMC gene expression in a series of human Leydig cell tumors. In this report we show that on occasion, tumors with such large amounts of pituitary-like 1,200-nt POMC transcripts are accompanied by a dramatic rise in the production of POMC peptides. 


\section{Methods}

Patients and tissue collection. The patients with Leydig cell tumors were adult males presenting with gynecomastia. The diagnosis was established on the usual laboratory data showing increased basal and human chorionic gonadotropin-stimulated estradiol plasma levels (35), and on the finding of a unilateral testicular tumor at physical examination and/or by ultrasonography. It was confirmed by histological examination. Tissue slides stained with hematoxylin eosin Safran showed typical eosinophilic Leydig cell population arranged in cords and trabeculae with a capillary stroma remodeled by discrete sclerosis. The tumors were separated from the normal testis by a pseudo-capsule. In all cases, Leydig cells appeared highly homogeneous, accounting for at least $80 \%$ of the tumor tissue. Occasional Reinke crystalloids were observed.

Leydig cell tumors and normal testes from patients castrated for the treatment of prostate cancer, were obtained at surgery. Normal human pituitary was collected at autopsy $6 \mathrm{~h}$ postmortem. All tissue fragments for biochemical studies were immediately frozen in liquid nitrogen and stored at $-80^{\circ} \mathrm{C}$.

Isolation of RNA. Total RNA was extracted by the guanidium chloride method (36) with minor modifications (37). Briefly, frozen tissues were homogenized at $4^{\circ} \mathrm{C}$ in $20 \mathrm{vol}(\mathrm{wt} / \mathrm{vol})$ of prechilled 0.02 $\mathrm{M}$ sodium acetate buffer, $\mathrm{pH} 5$, containing $7 \mathrm{M}$ guanidine $\mathrm{HCl}$. $\mathrm{Nu}-$ cleic acids were ethanol precipitated and DNA was removed by three washes in $3 \mathrm{M}$ sodium acetate buffer, $\mathrm{pH}$ 5. After centrifugation the pellet was washed twice with $80 \%$ ethanol, dried, and resuspended in sterile water. Total cellular RNA yields were in the range of $0.5-1.5$ $\mathrm{mg} / \mathrm{g}$ wet wt tissue. Poly (A) ${ }^{+}$RNA was isolated by oligodT cellulose chromatography.

Probe preparation. Single-strand DNA probes were prepared by extension from the M13 universal primer using POMC genomic M13 templates as described (33). Two probes were synthesized: pHOX 3A was complementary to the Sma I-Sal I 657-nt fragment of the third exon and comprised the main part of the coding region of this exon; pHOX 1 was complementary to the entire exon 1 of the human gene. Specific activity usually ranged from 1 to $2 \times 10^{9} \mathrm{cpm} / \mu \mathrm{g}$ DNA.

RNA blot analysis. $20 \mu \mathrm{g}$ of total RNA or $5 \mu \mathrm{g}$ of poly (A) ${ }^{+}$RNA were denatured in $10 \mathrm{mM} \mathrm{CH}_{3} \mathrm{HgOH}$, size fractionated on $2 \%$ agarose gels containing $10 \mathrm{mM} \mathrm{CH}_{3} \mathrm{HgOH}$ and blotted onto nylon membranes (Hybond N; Amersham Corp., Arlington Heights, IL). After UV cross-linking the membranes were prehybridized and hybridized at $65^{\circ} \mathrm{C}$ in the same buffer: $3 \times$ standard saline citrate (SSC), $10 \%$ polyethylene glycol $6,000,1 \%$ SDS, $1 \%$ glycine, $0.1 \%$ polyvinylpirolidone, $0.1 \%$ Ficoll, and $100 \mu \mathrm{g} / \mathrm{ml}$ of denatured sheared salmon sperm DNA. After a 4-h prehybridization period, filters were hybridized $40 \mathrm{~h}$ with $2-5 \times 10^{6} \mathrm{cpm} / \mathrm{ml}(2-4 \mu \mathrm{g} / \mathrm{ml})$ of single-strand POMC DNA probe. Washes were done at $65^{\circ} \mathrm{C}, 2 \mathrm{~h}$ in $1 \times \mathrm{SSC}, 1 \% \mathrm{SDS}, 1 \mathrm{~h}$ in $0.2 \times \mathrm{SSC}$, $1 \%$ SDS and then exposed to $x$-ray films (Eastman Kodak Corp.) at $-80^{\circ} \mathrm{C}$ with intensifying screens (Lightning Plus; Dupont Co., Wilmington, DE).

Peptide extraction. Except for tumors 1 and 2, tissue fragments were homogenized in ice-cold $5 \mathrm{~N}$ acetic acid $(10 \mathrm{ml} / \mathrm{g}$ tissue) containing $1 \mathrm{mM}$ PMSF by 3-5 15-s bursts in a $\mathrm{PCU}_{2}$ Polytron (Polytron Corp., Elkhart, IN). The homogenates were centrifuged at $5,000 \mathrm{~g}$ for $30 \mathrm{~min}$ at $4^{\circ} \mathrm{C}$, and the supernatants were lyophilized in multiple aliquots that were subsequently used for RIA and/or chromatographic studies.

POMC peptide content in tumors 1 and 2 were estimated in the crude guanidine supernatant resulting from RNA preparation through a Sephadex G 10 column after salt elimination by gel exclusion chromatography. The fractions in the void volume were then pooled, aliquoted, and lyophilized.

RIAs. A series of different RIAs directed against the $\mathrm{COOH}-$ terminal half of the human (h) POMC molecule were used.

A specific ACTH RIA was performed using the mid-ACTH antibody C22. Synthetic hACTH was used as both standard and tracer. No significant cross-reactivity was observed with hNT, CLIP, h $\beta L P H$, $\mathrm{h} \gamma \mathrm{LPH}, \mathrm{h} \beta \mathrm{MSH}$, or $\mathrm{h} \beta \mathrm{end}$.

A COOH-terminal h $\gamma$ LPH RIA was performed as described (37) using antibody 1547 . Highly purified $\mathrm{h} \gamma \mathrm{LPH}$ was used both as standard and tracer. Synthetic h $\beta$ MSH and $\mathrm{h} \beta \mathrm{MSH}_{5-22}$ showed $100 \%$ cross-reactivity. No significant cross-reactivity was observed with hNT, hCLIP, hACTH, and h $\beta$ LPH. A mid-hLPH RIA was performed similarly with antibody 3345 (38). Contrary to the previous RIA, h $\beta$ LPH and $\mathrm{h} \beta \mathrm{MSH}$ showed $100 \%$ cross-reactivity, and $\mathrm{h} \beta \mathrm{MSH}_{5-22}$ had no cross-reactivity.

The $h \beta$ end RIA was performed as described (39) using antibody $R$ 2489. Synthetic $h \beta$ end was used both as standard and tracer. Purified h $\beta$ LPH showed $100 \%$ cross-reactivity. No significant cross-reactivity

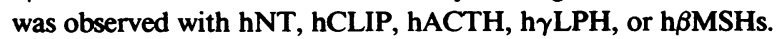

The lyophilized tissue extracts were redissolved in $0.1 \mathrm{~N} \mathrm{HCl}$, centrifuged at $5,000 \mathrm{~g}$ for $30 \mathrm{~min}$ at $4^{\circ} \mathrm{C}$, and the supernatant serially diluted in the appropriate buffer for RIA measurement and/or for chromatography.

Sephadex G-75 gel exclusion chromatography. A $0.9 \times 60 \mathrm{~cm}$ column was packed with Sephadex G-75 Fine (Pharmacia Fine Chemicals, Piscataway, NJ), which was equilibrated and developed at $4^{\circ} \mathrm{C}$ in $1 \%$ formic acid, $0.2 \%$ BSA. Samples of $0.8 \mathrm{ml}$ were applied and eluted at a flow rate of $20 \mathrm{ml} / \mathrm{h}$ (descending flow, $50 \mathrm{~cm}$ hydrostatic pressure), and $1-\mathrm{ml}$ fractions were collected. The column was calibrated with BSA as a void volume marker, hACTH, $h \beta L P H, h \beta e n d, h \gamma L P H$, $\mathrm{h} \beta \mathrm{MSH}_{\text {5-22 }}$ (each measured by RIA), and DNP-alanine as a total volume marker. BSA and DNP-alanine were added to each sample to determine the fractional elution volume $\left(K_{\mathrm{av}}\right)$ of the immunoreactive materials for each run. Fractions eluted from the column were lyophilized, reconstituted in assay buffer, and analyzed by RIA.

HPLC. The LKB HPLC system (LKB Produkter, Bromma, Sweden) consisted of one 2150 pump, a 2152 controller, and a low pressure mixing chamber. Solvent $A$ was $15 \%$ acetonitrile, $0.1 \%$ trifluoroacetic acid in water and solvent $B$ was $65 \%$ acetonitrile, $15 \%$ methanol, $0.1 \%$ trifluoroacetic acid in water. The eluates from Sephadex G-75 were reconstituted in $0.2 \mathrm{ml}$ of solvent $A$ and loaded onto a $C_{8} R P 300$ Aquapore column (Brownlee Labs, Santa Clara, CA). The column was then eluted at constant flow rate of $1.5 \mathrm{ml} / \mathrm{min}$ with a linear gradient over $56 \mathrm{~min}$ from 0 to $30 \% \mathrm{~B}\left(15-30 \% \mathrm{CH}_{3} \mathrm{CN}\right)$. Fractions $(0.75 \mathrm{ml})$ were collected every $30 \mathrm{~s}$ by a Helirac 2212 fraction collector, lyophilized, and analyzed by RIA.

\section{Results}

Analysis of POMC transcripts. RNA from eight normal testes were examined by blot hybridization with the $\mathrm{pHOX} 3 \mathrm{~A}$ probe (Fig. 1). Variable amounts of a highly predominant RNA species were detected in all samples, demonstrating that POMC gene expression is a constant feature of this tissue. Comparison with normal human pituitary (Fig. 1, lane $P$ ) indicated that this signal corresponded to the previously characterized 800-nt POMC RNAs. The same probe was used to examine RNAs extracted from six human Leydig cell tumors (Fig. 2); whereas the 800-nt mRNA was similarly present, a second signal identical to the 1,200-nt pituitary mRNA could be detected in five of the six tumors. RNA extracted from the adjacent, nontumoral region of three of the Leydig cell tumors only contained the 800-nt RNAs, as in normal testis (Fig. $3 A$, lane $T$, and data not shown). Tumors 1 and 2 , which contained the highest amounts of the 1,200-nt POMC, mRNA, were analyzed further with the pHOX 1 probe (Fig. $3 \mathrm{~B}$ ); as expected, none of the 800-nt RNAs contained exon 1 sequences, whereas the 1,200-nt mRNAs were similarly hybridized whether they originated from the normal pituitary or the tumoral Leydig cells. $S_{1}$ mapping studies further showed that the start site of transcrip- 


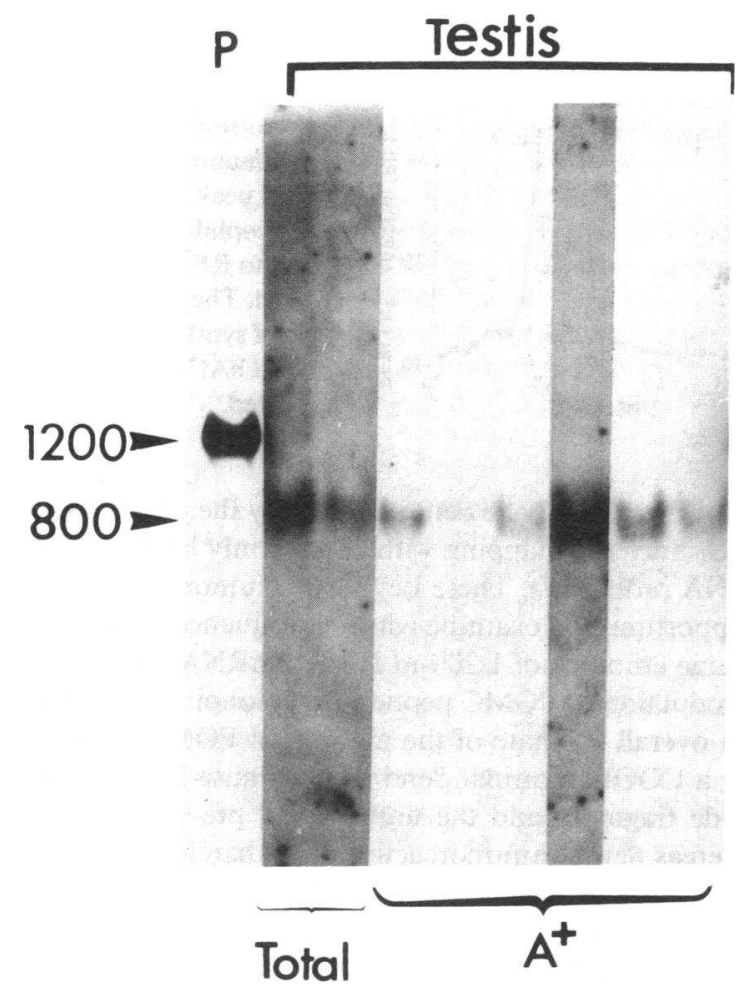

Figure 1. Blot hybridization of normal testis RNA. Total pituitary RNA (1 $\mu \mathrm{g}$, lane $P$ ), and total $(20 \mu \mathrm{g})$ and poly $\mathrm{A}^{+}(5 \mu \mathrm{g})$ RNA from normal testis were denatured in $10 \mathrm{mM}$ methylmercuric hydroxide and separated on a denaturing $2 \%$ agarose gel. The RNAs were blotted onto a Gene Screen Plus Sheet and hybridized with the uniformly labeled pHOX $3 \mathrm{~A}$ probe. The sheet was exposed $3 \mathrm{~d}$ at $-80^{\circ} \mathrm{C}$.

tion of the tumoral 1,200-nt mRNAs corresponded to that in the pituitary (data not shown), thus confirming that the 1,200nt tumor gene product was identical to the pituitary POMC mRNA.

Analysis of POMC peptides. The content of POMC peptides in the tumors was first evaluated by direct RIA of the

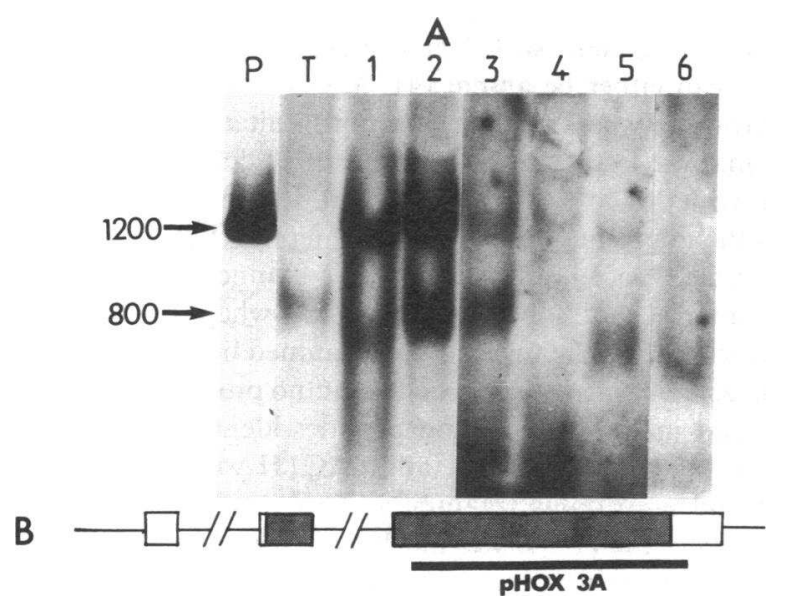

Figure 2. Total RNA from six human Leydig cell tumors $(20 \mu \mathrm{g}$; $1-6)$, a normal testis ( $20 \mu \mathrm{g} ; T)$, and a normal pituitary ( $1 \mu \mathrm{g} ; P)$, were analyzed as in Fig. 1.

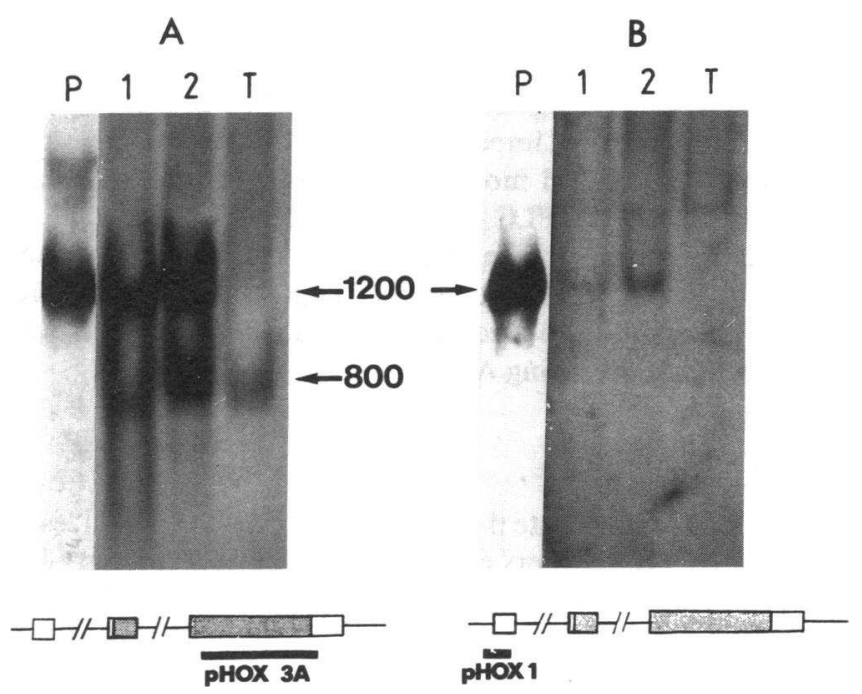

Figure 3. Blot hybridization of normal and tumoral testis RNA with two different probes. $(A)$ Pituitary total RNA $(1 \mu \mathrm{g} ; P)$ and total RNA $(20 \mu \mathrm{g})$ from two Leydig cell tumors (1 and 2), and the peritumoral testis of tumor $2(T)$, hybridized with probe pHOX 3A shown at the bottom. $(B)$ The same filter was rehybridized with probe pHOX 1 shown at the bottom.

crude desalted guanidine supernatant or tissue extract using a COOH-terminal hßend RIA, which recognized the unprocessed precursor as well (it was determined that the two different extraction methods gave the same results in other tumors). Whereas $\beta$ end immunoreactivity was barely detectable in extracts of 10 normal human testes, it was at least a thousand times higher in Leydig cell tumors 1 and 2, although still far from that in the pituitary, and significantly increased in tumor 3 (Table I).

The high content of POMC peptides in tumors 1 and 2 allowed a fine evaluation of the precursor processing. The combined use of Sephadex G-75 gel exclusion chromatography and RIA of the collected fractions with a battery of antisera, demonstrated the presence of peptides similar to

Table I. Tissue Content in Immunoreactive hßend (pg/mg Wet Weight)

\begin{tabular}{rrrrr}
\hline & \multirow{2}{*}{ Normal testes } & & \multicolumn{2}{c}{ Leydig cell tumors } \\
\cline { 5 - 5 } Case No. & Peptide* & & Case No. & Peptide* \\
\cline { 5 - 5 } 1 & 5 & 1 & 3430 \\
2 & $<9$ & 2 & 1450 \\
3 & 4 & 3 & 17 \\
4 & 2 & 4 & $<1$ \\
5 & $<1$ & 5 & $<2$ \\
6 & $<1$ & & \\
7 & $<1$ & & \\
8 & 3 & & \\
9 & $<1$ & & \\
10 & $<6$ & & & \\
& & & & \\
\hline
\end{tabular}

* Immunoreactive $\mathrm{h} \beta$ end, $\mathrm{pg} / \mathrm{mg}$ wet weight. 
(if not identical with) $\mathrm{h} \beta \mathrm{LPH}, \mathrm{h} \gamma \mathrm{LPH}, \mathrm{h} \beta \mathrm{end}$, ACTH, and $\mathrm{h} \beta \mathrm{MSH}_{5-22}$ (Fig. 4). No immunoreactive material was present in the void volume suggesting that the POMC processing was complete. Due to its important physiological functions, the integrity of the ACTH molecule was further examined by reverse phase (RP-) HPLC, which showed that true $\mathrm{ACTH}_{1-39}$ was indeed present in the tumor extract (Fig. 5). Thus, not only did the tumoral tissue produce large amounts of POMC but also processed the precursor molecule to generate its various fragments including ACTH.

\section{Discussion}

Our results demonstrate that in contrast with the normal testis, some Leydig cell tumors express a predominant pituitary-like 1,200-nt POMC transcript. That the appearance of the 1,200nt mRNA in the tumors was induced by, or concomitant with, the tumoral transformation, was reinforced by the fact that the peritumoral region of the Leydig cell tumors contained only the short 800-nt transcripts.

The short POMC RNAs lack exons 1 and 2 and cannot encode a complete POMC molecule. The absence of a signal peptide (entirely coded by exon 2 ) should further prevent the translocation of any translated protein into the rough endoplasmic reticulum compartment (40). The translation efficiency of the short RNAs has been questioned since POMC peptides in the normal testis are extremely low for the amount of transcripts (29); we have postulated that the small amounts of POMC peptides, which can actually be detected in the normal testis, are not generated from the translation of the short RNAs, but rather derive from a minor $(<1 \%)$ and barely detectable population of pituitary-like $(1,200 \mathrm{nt})$ POMC tran-

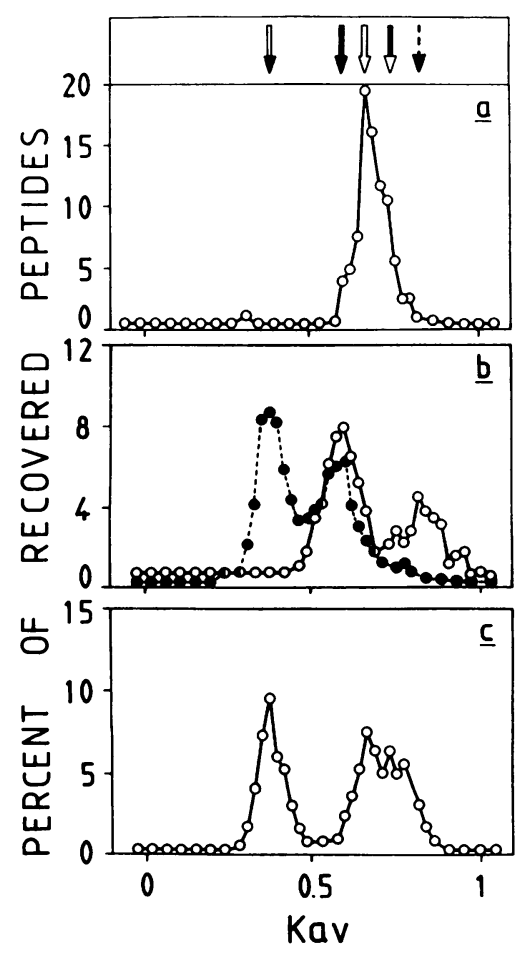

Figure 4. Sephadex G-75 Gel exclusion chromatography of extracts from the Leydig cell tumor 2. (a) Each collected fraction was lyophilized, reconstituted, and analyzed with the mid-ACTH RIA. (b) The hLPH RIA $(\bullet \cdots \bullet)$ and the C-h $\gamma$ LPH RIA (O - o). (c) The hßend RIA. The positions of the immunoreactive materials are shown on a fractional elution volume (Kav) scale; the relative amounts of the various immunoreactive material are shown as a percentage of recovered material. The elution volumes of highly purified $h \beta L P H(q)$ and h $\gamma$ LPH ( $($ ), synthetic hACTH (\&), hßend ( $₫)$, and $h \beta \mathrm{MSH}_{5-22}(\mathfrak{l})$ are indicated.

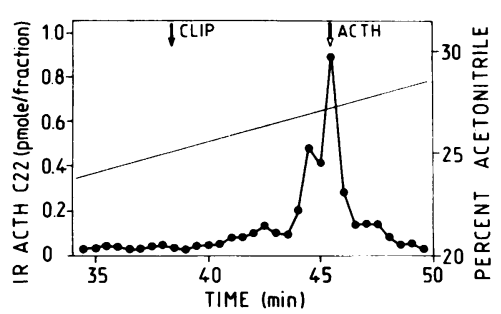

Figure 5. RP-HPLC of immunoreactive Leydig cell tumor ACTH. Fractions corresponding to the immunoreactive ACTH peak (Fig. $4 a$ ) were lyophilized and subjected to RP-HPLC as indicated. The retention time of synthetic hCLIP (๖) and hACTH ( $)$ are indicated.

scripts which could only be demonstrated by the use of highly sensitive $S_{1}$ nuclease mapping with a uniformly labeled single strand DNA probe (27). These Leydig cell tumors provided a unique opportunity to examine what consequence the appearance of large amounts of 1,200-nt POMC mRNA would have on the production of POMC peptides in a nonpituitary tissue.

As an overall estimate of the amount of POMC peptides, we chose a COOH-terminal $\beta$ end RIA because it recognized the peptide fragment and the unprocessed precursor as well (41). Whereas $\beta$ end immunoreactivity was barely measurable in extracts of 10 normal human testes, it was at least 1,000 -fold higher in the two Leydig cell tumors which contained the highest concentrations of the 1,200-nt POMC transcripts (Table I). The fact that the tumor tissue contains an almost homogeneous population of Leydig cells should only account for at most a 33-fold increase since the normal human testis contains between 3 and 19\% of Leydig cells (42).

Although it had not been specifically searched for by the usual laboratory investigations, a Cushing's syndrome apparently was not present in the two patients whose tumors contained high concentrations of POMC peptides. These tissue concentrations however remained far $(\sim 1,000$-fold lower $)$ from that in the normal and tumoral pituitaries (43). The exceptional cases of Cushing's syndrome associated with Leydig cell tumors resulted from the local secretion of cortisol (44).

Another crucial event in the overall mechanism of POMC gene expression is the post-translational processing of POMC which determines whether ACTH itself is produced and eventually secreted. Altered modes of POMC processing have been described in human ACTH-producing nonpituitary tumors, where it can either be absent $(41,45)$ or exaggerated (33) in comparison to what occurs in anterior pituitary corticotrophs. In normal rat testis and in Leydig tumor cell lines peptides similar with des-acetylated- $\alpha \mathrm{MSH}$ and $\beta$ end have been identified as the major final products, showing that POMC processing does take place in this cell type in a manner similar to that in the intermediate lobe of the pituitary where no ACTH is generated (29). In the two tumors examined here, POMC processing actually proved highly efficient; no precursor molecule was found in the extracts and peptides identical to $h \beta L P H$, $\mathrm{h} \gamma \mathrm{LPH}, \mathrm{h} \beta$ end, $\mathrm{h} \beta \mathrm{MSH}_{5-22}$, and $\mathrm{hACTH}$ were identified as intact and equimolar fragments. Thus human Leydig cell tumors have the enzymatic machinery which may somehow process polypeptide precursors; and a major difference was that authentic $\mathrm{ACTH}_{1-39}$ was present in the human tumors.

Recently, various peptide hormones, and in some cases their mRNA, have been identified in cell types which were 
thought (up to now) to produce only steroid hormones; inhibin in the granulosa cells (46) and prorenin in the theca cells of the human ovary (47) are two examples. In the Leydig cell itself, renin (48), enkephalin (49), activin (50), and AVP (51) are other recent examples. The presence of AVP, as fully characterized by HPLC, is a further demonstration that polypeptide precursor processing can occur in the testis, also stressing the fact that processing enzymes may have a wide tissue distribution, although they are not present in all cell types (52).

The presence of secretory granules and their biochemical markers, the chromogranins, have been stressed as the specific hallmark of neuro-endocrine or peptide hormone secreting cells to discriminate them from other endocrine cells which produce steroid or thyroid hormones $(53,54)$. These secretory granules are also associated with a specific secretory mechanism called the regulatory pathway (55). It is now clear that peptide hormones may be secreted by steroid producing cells (50), of which the well known peptide secretions of the placenta is the best example (56). In our Leydig cell tumors, no chromogranin could be detected (data not shown), which suggests that if peptide hormone secretion did occur, it did so by a purely constitutive pathway. Thus the Leydig cell appears yet another endocrine cell type which can produce both steroidand peptide hormones.

Recently, questions have arisen as to the exact cellular origins of POMC transcripts in the testis. Rat and mouse testis germ cells have been demonstrated to contain POMC RNAs, whereas these same transcripts were undetectable in freshly fractionated Leydig cells $(24,49,57,58)$. Others have shown that specific Leydig cell destruction by the cytotoxic drug ethane dimethane sulphonate, neither altered the overall amount of POMC transcripts in the whole testis nor in the crude interstitial cell preparation (59), raising the possibility that other nongerm cells such as macrophages $(60,61)$ might be the site of POMC gene expression in the testis. These data are in direct contradiction with prior results obtained by immunocytochemical- and in situ hybridization techniques $(23,24)$ as well as with studies performed on Leydig cell lines (25). Although the tumor tissues which we examined did not contain a purely homogeneous population of Leydig cells, they were totally devoid of any germ cell and did not show any evidence of abnormal lymphocyte- or macrophage infiltration. Although they were obtained in tumor cells these results suggest that POMC gene expression does occur in Leydig cells.

Tumor transformation of Leydig cells might induce a different (or earlier) stage of cell differenciation with the reexpression of peptide hormone genes at a higher rate, using a different pituitary-like promotor. Alternatively, and perhaps more likely, a tumor might develop from a cell already expressing the pituitary-like POMC mRNA; it is possible that such cells exist as a minor population and are responsible for the small amount of pituitary-like transcripts which can be detected in the normal testis (27). It would also explain why only occasional Leydig cell tumors show this mode of POMC gene expression. In this regard, it is of interest to recall that transgenic mice injected with a chimeric rat POMCneo gene containing the rat POMC promoter region $(-706$ to +63$)$, express high levels of the transgene in the pituitary and at a much smaller rate in the testis (62). In the latter organ, RNase mapping shows a transcription initiation similar to that in the pituitary.
Our results show that in a tissue which normally expresses the POMC gene predominantly as a short, truncated RNA, activation of a pituitary promoter may induce a dramatic rise in the production of POMC peptides. We suggest that this phenomenon is occasionally caused by, or associated with, tumor transformation and is the first and mandatory step for the production of large amounts of POMC fragments such as ACTH.

\section{Acknowledgments}

We express our thanks to D. N. Orth and P. Lowry for their generous gift of purified peptides and antisera. We are also indebted to B. Debré for the collection of normal and tumoral human testes. We thank Mrs. Le Scouarnec for her excellent secretarial assistance.

This work was supported in part by Contrat de Recherche Externe INSERM 894003 and Association pour la Recherche contre le Cancer contrat 3465 .

\section{References}

1. Eipper, B. A., and R. E. Mains. 1980. Structure and biosynthesis of pro-adrenocorticotropin/endorphin and related peptides. Endocr. Rev. 1:1-27.

2. Nakanishi, S., A. Inoue, T. Kita, M. Nakamura, A. C. Y. Chang, S. N. Cohen, and S. Numa. 1979. Nucleotide sequence of cloned cDNA for bovine corticotropin- $\beta$-lipotropin precursor. Nature (Lond.). 278:423-427.

3. Roberts, J. L., P. Seeburg, J. Shine, E. Herbert, J. D. Baxter, and H. M. Goodman. 1979. Corticotropin and beta endorphin: construction and analysis of recombinant DNA complementary to mRNA for the common precursor. Proc. Natl. Acad. Sci. USA. 76:2153-2157.

4. Whitfeld, P., P. Seeburg, and J. Shine. 1982. The human proopiomelanocortin gene: organization, sequence and interspersion with repetitive DNA. DNA (NY). 1:133-143.

5. Takahashi, H., Y. Hakamata, U. Watanabe, R. Kikuno, T. Miyata, and S. Numa. 1983. Complete nucleotide sequence of the human corticotropin- $\beta$-lipotropin precursor gene. Nucleic Acids Res. 11:6847-6858.

6. Drouin, J., M. Chamberland, J. Charron, L. Jeannotte, and M. Nemer. 1985. Structure of the rat proopiomelanocortin (POMC) gene. FEBS (Fed. Eur. Biochem. Soc.) Lett. 193:54-58.

7. Nakanishi, S., Y. Ternishi, Y. Watanabe, M. Notake, M. Noda, H. Kakidani, H. Jingami, and S. Numa. 1981. Isolation and characterization of the bovine corticotropin/ $\beta$-lipotropin precursor gene. Eur. $J$. Biochem. 115:429-438.

8. Uhler, M., E. Herbert, P. Deustachio, and F. D. Ruddle. 1983. The mouse genome contains two nonallelic pro-opiomelanocortin genes. J. Biol. Chem. 258:9444-9453.

9. Notake, M., T. Tobimatsu, Y. Watanabe, H. Takahashi, M. Mishina, and S. Numa. 1983. Isolation and characterization of the mouse corticotropin- $\beta$-lipotropin precursor gene and a related pseudogene. FEBS (Fed. Eur. Biochem. Soc.) Lett. 156:67-71.

10. Nakanishi, S., T. Kita, S. Taii, H. Imura, and S. Numa. 1977. Glucocorticoid effect on the level of corticotropin messenger RNA activity in rat pituitary. Proc. Natl. Acad. Sci. USA. 74:3283-3287.

11. Schachter, B. S., L. K. Johnson, J. D. Baxter, and J. L. Roberts. 1982. Differential regulation by glucocorticoids of proopiomelanocortin mRNA levels in the anterior and intermediate lobes of the rat pituitary. Endocrinology. 110:1442-1444.

12. Birnberg, N. C., J. C. Lissitzky, M. Hinman, and E. Herbert. 1983. Glucocorticoids regulate proopiomelanocortin gene expression in vivo at the levels of transcription and secretion. Proc. Natl. Acad. Sci. USA. 80:6982-6986.

13. Chen, C. L., F. T. Dionne, and J. L. Roberts. 1984. Regulation of the proopiomelanocortin mRNA levels in rat pituitary by dopaminergic compounds. Proc. Natl. Acad. Sci. USA. 80:2211-2215. 
14. Lundblad, J. R., and J. L. Roberts. 1988. Regulation of proopiomelanocortin gene expression in pituitary. Endocr. Rev. 9:135158.

15. Seidah, N., J. Rochemont, J. Hamelin, M. Lis, and M. Chretien. 1981. Primary structure of the major human pituitary proopiomelanocortin $\mathrm{NH}_{2}$-terminal glycopeptide. J. Biol. Chem. 256:79777984.

16. Allen, R. G., E. Orwoll, J. W. Kendall, and E. Herbert. 1980. The distribution of forms of adrenocorticotropin and $\beta$-endorphin in normal, tumorous and autopsy human anterior pituitary tissues: virtual absence of $13 \mathrm{~K}$ adrenocorticotropin. J. Clin. Endocrinol. Metab. 51:376-380.

17. Tanaka, K., W. E. Nicholson, and D. N. Orth. 1978. The nature of immunoreactive lipotropins in human plasma and tissue extracts. $J$. Clin. Invest. 62:94-104.

18. Bertagna, X., D. Seurin, L. Pique, J. P. Luton, H. Bricaire, and F. Girard. 1983. Peptides related to the $\mathrm{NH}_{2}$ terminal end of pro-opiomelanocortin in man. J. Clin. Endocrinol. Metab. 56:489-495.

19. Bertagna, X., F. Camus, F. Lenne, F. Girard, and J. P. Luton. 1988. Human joining peptide: a proopiomelanocortin product secreted as a homodimer. Mol. Endocrinol. 2:1108-1114.

20. Scott, A. P., P. J. Lowry, J. G. Ratcliffe, L. H. Rees, and J. Landon. 1974. Corticotropin-like peptides in the rat pituitary. J. Endocrinol. 61:355-367.

21. Scott, A. P., and P. J. Lowry. 1974. Adrenocorticotrophic and melanocyte-stimulating peptides in the human pituitary. Biochem. J. 139:593-602.

22. Krieger, D. T. 1983. The multiple faces of proopiomelanocortin, a prototype precursor molecule. Clin. Res. 31:342-353.

23. Tsong, S. D., D. Philipps, N. Halmi, D. T. Krieger, and C. W. Bardin. 1982. $\beta$ endorphin is present in the male reproductive tract of five species. Biol. Reprod. 27:755-764.

24. Gizang-Ginsberg, E., and D. J. Wolgemuth. 1985. Localization of mRNAs in mouse testis by in situ hybridization: distribution of alpha-tubulin and developmental stages specificity of proopiomelanocortin transcripts. Dev. Biol. 111:293-305.

25. Chen, C. L., J. P. Mather, P. L. Morris, and C. W. Bardin. 1984. Expression of pro-opiomelanocortin-like gene in the testis and epididymis. Proc. Natl. Acad. Sci. USA. 81:5672-5675.

26. Pintar, J. E., B. S. Shacter, A. B. Herman, S. Durgerian, and D. T. Krieger. 1984. Characterization and localization of pro-opiomelanocortin messenger RNA in the adult rat testis. Science (Wash. DC). 225:632-634.

27. Lacaze-Masmonteil, T., Y. de Keyzer, J. P. Luton, A. Kahn, and X. Bertagna. 1987. Characterization of Proopiomelanocortin transcripts in human non-pituitary tissues. Proc. Natl. Acad. Sci. USA. 84:7261-7265.

28. Jeannotte, L., J. P. H. Burbach, and J. Drouin. 1987. Unusual proopiomelanocortin ribonucleic acids in extrapituitary tissues: intronless transcripts in testes and long poly (A)+ tails in hypothalamus. Mol. Endocrinol. 1:749-757.

29. Bardin, C. W., C. Shaha, J. Mather, Y. Salomon, A. N. Margioris, A. S. Liotta, I. Gerendai, C. L. Chen, and D. T. Krieger. 1984. Identification and possible function of pro-opiomelanocortin-derived peptides in the testis. Ann. NY Acad. Sci. 438:346-364.

30. De Bold, C. R., W. E. Nicholson, and D. N. Orth. 1988. Immunoreactive proopiomelanocortin (POMC) peptides and POMC-like messenger ribonucleic acid are present in many rat nonpituitary tissues. Endocrinology. 122:2648-2657.

31. Tsukada, T., Y. Nakai, J. Jingami, S. Imura, S. Tall, S. Nakanishi, and S. Numa. 1981. Identification of the mRNA coding for the ACTH-lipotropin precursor in a human ectopic ACTH-producing tumor. Biochem. Biophys. Res. Commun. 98:535-540.

32. De Bold, C. R., M. E. Schowerer, T. B. Connor, R. E. Bird, and D. N. Orth. 1983. Ectopic pro-opiomelanocortin: sequence of cDNA coding for $\beta$-melanocyte stimulating hormone and $\beta$-endorphin. Science (Wash. DC). 220:721-723.

33. De Keyzer, Y., X. Bertagna, F. Lenne, F. Girard, J. P. Luton, and A. Kahn. 1985. Altered proopiomelanocortin gene expression in ACTH producing nonpituitary tumors. J. Clin. Invest. 76:1892-1898.

34. De Keyzer, Y., M. F. Rousseau-Merck, J. P. Luton, F. Girard, A. Kahn, and X. Bertagna. 1989. Pro-opiomelanocortin gene expression in human phaeochromocytomas. J. Mol. Endocrinol. 2:175-181.

35. Kuhn, J. M., J. Mahoudeau, L. Billaud, J. Joly, M. Rieu, A. Gancel, F. Archambeaud-Mouveroux, A. Steg, and J. P. Luton. 1987. Evaluation of diagnostic criteria for Leydig cell tumor in adult men revelated by gynecomastia. Clin. Endocrinol. 26:407-416.

36. Cox, R. A. 1968. The use of guanidium chloride in the isolation of nucleic acid. Methods Enzymol. 13:120-129.

37. Kahn, A., D. Cottreau, D. Daegelen, and J. C. Dreyfus. 1981. Cell free translation of messenger RNAs from adult and fetal human muscle. Eur. J. Biochem. 116:7-12.

38. Bertagna, X., F. Lenne, D. Comar, J. F. Massias, H. Wajcman, V. Baudrin, J. P. Luton, and F. Girard. 1986. Human $\beta$ Melanocyte stimulating hormone revisited. Proc. Natl. Acad. Sci. USA. 83:97199723.

39. Bertagna, X. Y., W. J. Stone, W. E. Nicholson, C. D. Mount, and D. N. Orth. 1981. Simultaneous assay of immunoreactive $\beta$-lipotropin, gamma-lipotropin, and $\beta$-endorphin in plasma of normal human subjects, patients with ACTH/lipotropin hypersecretory syndromes, and patients undergoing chronic hemodialysis. J. Clin. Invest. 67:124-133.

40. Walter, P., R. Gilmore, and G. Blobel. 1984. Protein translocation across the endoplasmic reticulum. Cell. 38:5-8.

41. Bertagna, X., W. E. Nicholson, G. D. Sorenson, O. S. Pettengill, C. D. Mount, and D. N. Orth. 1978. Corticotropin, lipotropin, and $\beta$-endorphin production by a human non-pituitary tumor in tissue culture: evidence for a common precursor. Proc. Natl. Acad. Sci. USA. 75:5160-5164.

42. Mori, H., N. Hiromoto, M. Nakahara, and T. Shiraishi. 1982. Stereological analysis of Leydig cell ultrastructure in aged humans. $J$. Clin. Endocrinol. Metab. 55:634-641.

43. Suda, T., H. Demura, R. Demura, K. Jibiki, F. Tazawa, K. Shizume. 1980. Anterior pituitary hormones in plasma and pituitaries from patients with Cushing's syndrome. J. Clin. Endocrinol. \& Metab. 51:1048-1053.

44. Knyrim, K., M. Higi, D. K. Hossfeld, S. Seeber, and C. G. Schmidt. 1981. Autonomous cortisol secretion by a metastatic leydig cell carcinoma associated with Klinefelter's syndrome. J. Cancer Res. Clin. Oncol. 100:85-93.

45. Yalow, R. S., and S. A. Berson. 1971. Size heterogeneity of immunoreactive human ACTH in plasma and in extracts of pituitary glands and ACTH-producing thymoma. Biochem. Biophys. Res. Commun. 44:439-445.

46. Ying, S. Y. 1988. Inhibins, activins, and follistatins: gonadal proteins modulating the secretion of follicle-stimulating hormone. Endocr. Rev. 9:267-293.

47. Do, Y. S., A. Sherrod, R. A. Lobo, R. J. Palson, T. Shinagawa, S. Chen, S. Kjos, and W. A. Hsueh. 1988. Human ovarian theca cells are a source of renin. Proc. Natl. Acad. Sci. USA. 85:1957-1961.

48. Deschepper, C. F., S. H. Mellon, F. Cumin, J. D. Baxter, and W. F. Gannong. 1986. Analysis by immunocytochemistry and in situ hybridization of renin and its mRNA in kidney, testis, adrenal, and pituitary of the rat. Proc. Natl. Acad. Sci. USA. 83:7552-7556.

49. Garrett, J. E., and J. O. Douglass. 1989. Human chorionic gondotropin regulates expression of the proenkephalin gene in adult rat leydig cells. Mol. Endocrinol. 3:2093-2100.

50. Lee, W., A. J. Mason, R. Schwall, E. Szonyi, and J. P. Mather. 1989. Secretion of activin by interstitial cells in the testis. Science (Wash. DC). 243:396-398.

51. Clements, J. A., and J. W. Funder. 1986. Arginine vasopression (AVP) and AVP-like immunoreactivity in peripheral tissues. Endocr. Rev. 7:449-460.

52. Thomas, G., B. A. Thorne, L. Thomas, R. G. Allen, D. E. Hruby, R. Fuller, and J. Thorner. 1988. Yeast KEX 2 endopeptidase 
correctly cleaves a neuroendocrine prohormone in mammalian cells. Science (Wash. DC). 241:226-230.

53. O'Connor, D. T., D. Burton, and J. L. Deftos. 1983. Immunoreactive human chromogranin $A$ in diverse polypeptide hormone producing human tumors and normal endocrine tissues. J. Clin. Endocrinol. Metab. Clin. North Am. 57:1084-1086.

54. Lassmann, H., C. Hagn, R. Fisher-Colbrie, and H. Winkler. 1986. Presence of chromogranin A, B and C in bovine endocrine and nervous tissues: a comparative immunohistochemical study. Histochem. J. 18:380-386.

55. Kelly, R. E. 1985. Pathways of protein secretion in eukaryotes. Science (Wash. DC). 230:25-32.

56. Germain, G., and F. Ferre. 1987. Hormones et parturition chez le primate. Ann. Endocr. 48:311-321.

57. Gizang-Gingsberg, E., and D. J. Wolgemuth. 1987. Expression of the proopiomelanocortin gene is developmentally regulated and affected by germ cells in the male mouse reproductive system. Proc. Natl. Acad. Sci. USA. 84:1600-1604.

58. Kilpatrick, D. L., K. Borland, and D. F. Jin. 1987. Differential expression of opioid peptide genes by testicular germ cells and somatic cells. Proc. Natl. Acad. Sci. USA. 84:5695-5699.

59. Li, H., G. P. Risbridger, J. W. Funder, and J. A. Clements. 1989. Effect of ethane dimethane sulphonate on proopiomelanocortin (POMC) mRNA and POMC-derived peptides in the rat testis. Mol. Cell. Endocrinol. 65:203-207.

60. Lolait, S. J., J. A. Clements, A. J. Markwich, C. Cheng, M. McNally, A. I. Smith, and J. W. Funder. 1986. Proopiomelanocortin messenger ribonucleic acid and posttranslational processing of $\beta$ endorphin in spleen macrophages. J. Clin. Invest. 77:1776-1779.

61. Buzzetti, R., L. McLoughlin, P. M. Lavender, A. J. L. Clark, and L. H. Rees. 1989. Expression of proopiomelanocortin gene and quantification of adrenocorticotropic hormone-like immunoreactivity in human normal peripheral mononuclear cells and lymphoid and myeloid malignancies. J. Clin. Invest. 83:733-737.

62. Tremblay, Y., I. Tretjakoff, A. Peterson, T. Antakly, C. Xian Zhang, and J. Drouin. 1988. Pituitary-specific expression and glucocorticoid regulation of a pro-opiomelanocortin (POMC) fusion gene in transgenic mice. Proc. Natl. Acad. Sci. USA. 85:8890-8894. 